\title{
COACHING DALAM AGENDA HABITUASI DITINJAU DARI MODEL GROW
}

\author{
Machmudan \\ Badan Kepegawaian dan Pengembangan Sumberdaya Manusia Kabupaten Natuna \\ Article history \\ Received: 7 Agustus 2020 \\ Revised : 14 Agustus 2020 \\ Accepted : 21 Agustus 2020 \\ ${ }^{*}$ Corresponding author \\ Machmudan \\ Email : machmudansadik@gmail.com
}

\begin{abstract}
Training supported by coaching was convinced as effective method to increase personell or organization performance. Pre service training for civil servant candidate also using coaching as method in habituation agenda, but is not use specific coaching model, coaching is not effective yet to increase civil servant candidate performance in habituation agenda. This study aims to describe coaching in habituation agenda in pre service training related goal, reality, option, and will. This study is literature study research by qualitative approach, using GROW coaching model formulating by Sir John Whitmore. The data were collected using literature study and document. Result of the study found that: coaching in habituation agenda related by goal including understanding goal, setting goal, and result in habituation agenda; reality including define organization issue, setting creative problem solving, deciding solution in actualization plan; option including set activities and step of activities, output, analyzing relations between activities with civil servant basic value, analyzing relations between activities with vision and mission of organization, analyzing relations between activities with strengthening organization value and actualization plan seminar presentation; and will including implementing of actualization, reporting, and actualization seminar presentation. It is neccesarry to coach in habituation agenda for coach and coachee related by goal, reality, option, and will in appropriate quality and skillful coaching.
\end{abstract}

Keywords: coaching, pre service training for civil servant candidate, GROW model

(C) 2020 Pusdiklat Perdagangan. All rights reserved

\section{PENDAHULUAN}

\section{A. Latar Belakang}

Pelatihan kepada pegawai yang didukung coaching mampu meningkatkan kinerja pegawai dan organisasi. Coaching dewasa ini dipercaya sebagai metode pengembangan sumber daya manusia yang efektif dalam meningkatkan kinerja pegawai dan organisasi. Demikian pula pada pelatihan dasar CPNS didukung coaching pada agenda habituasi sebagaimana diatur dalam Peraturan LAN
Nomor 12 Tahun 2018 Tentang Pelatihan Dasar CPNS. Agenda habituasi merupakan pembelajaran yang memfasilitasi peserta melaksanakan aktualisasi melalui pembiasaan diri terhadap kompetensi yang telah diperolehnya melalui berbagai Mata Pelatihan yang telah dipelajari.

Coaching pada agenda habituasi dilakukan antara coach (widyaiswara) dan coachee (peserta pelatihan) melalui proses tatap muka meliputi penyusunan dan penyajian 
rancangan aktualisasi di tempat pelatihan, dan proses coaching jarak jauh atau daring menggunakan teknologi informasi seperti email, whatsapp, media sosial, dan lain-lain meliputi aktualisasi di tempat kerja coachee, penyusunan dan penyajian hasil aktualisasi pada akhir pelatihan.

Coaching dalam agenda habituasi belum sepenuhnya efektif mencapai tujuan agenda habituasi. Permasalahan ini berdampak pada penyusunan rancangan aktualisasi, pelaksanaan aktualisasi, dan hasil aktualisasi belum sepenuhnya mencapai tujuan agenda habituasi. Hal ini disebabkan coaching pada agenda habituasi belum ditentukan modelnya secara spesifik. Coaching dilaksanakan berdasarkan pemahaman dan pengalaman masing-masing coach sesuai materi coaching pada workshop atau training of trainer Pelatihan Dasar CPNS yang diikuti coach.

Untuk menjelaskan permasalahan penelitian ini digunakan coaching model GROW. Coaching model GROW dipilih karena menurut pendapat Whitmore (2017:98), "It was simple and because it was actions and outcome focused, GROW become world famous and one of the most popular coaching model globally (model ini sederhana dan karena model ini fokus pada aksi dan outcome, GROW menjadi terkenal dan salah satu model coaching paling popular di dunia). Coaching model GROW juga selaras dengan tahapan agenda habituasi yaitu menyusun dan menyajikan rancangan aktualisasi di tempat pelatihan, aktualisasi di tempat kerja, menyusun dan menyajikan hasil aktualisasi.

Kajian ini diharapkan memberikan gambaran secara menyeluruh tentang proses coaching pada Latsar CPNS ditinjau dari coaching model GROW (Goal, Reality, Opportunity, dan Will) dan memberikan rekomendasi penyelesaian atas permasalahan tersebut.

\section{B. Kajian Teoritis}

\section{1) Pengertian Coaching}

Banyak definisi tentang coaching yang dikemukakan para pakar atau praktisi. Coaching is unlocking people's potential to maximamize their own performance (coaching adalah membuka kunci potensi seseorang untuk meningkatkan kinerjanya, Whitmore, 2017:12), memberdayakan orang lain dengan memfasilitasi pembelajaran diri, pertumbuhan pribadi, dan perbaikan kinerja (Passmore, 2010:4), proses kolaborasi yang berfokus pada solusi, berorientasi pada hasil, dan sistematis, dimana coach memfasilitasi peningkatan atas performa kerja, pengalaman hidup, pembelajaran diri, dan pertumbuhan pribadi dari coachee (Grant, 1999: definisi dasar juga juga mengacu pada Association for Coaching, 2005), hubungan profesional antara coach yang berkualitas individu atau kelompok guna mendukung pencapaian hasil yang luar biasa berdasarkan tujuan yang telah ditetapkan oleh individu atau kelompok tersebut (ICF, 2005), 'bertanya beberapa pertanyaan yang membantu orang-orang menemukan jawaban yang tepat untuk mereka' (Ed Batista, 2015:xi), coaching with compassion sebagai membantu seseorang untuk mengeksplorasi dan mengartikulasi idenya dan sebuah visi untuk masa depannya sendiri, membantu seseorang menemukan perbedaan antara ide yang dia miliki dan keharusan yang dia miliki (Boyafitz, dkk., 2019:49).

Kaswan (2012:12) merangkum pendapat pakar sebagai berikut: O'Connor dan Lages (2007:13) coaching adalah perubahan kognitif, emosi, yang memfasilitasi pencapaian sasaran dan peningkatan kinerja seseorang atau kehidupan pribadi (Douglas dan McCauauley, 1999), seni memfasilitasi kinerja, pembelajaran, dan perkembangan orang lain (Downey, 1999), membekali orang dengan peralatan, pengetahuan, dan kesempatan yang mereka perlukan untuk mengembangkan dirinya dan untuk menjadi lebih efektif (Peterson dan Hicks, 1999), membantu seseorang dengan cara yang dikehendakinya dan membantunya menuju arah yang hendak dicapainya, mendukung seseorang pada setiap level untuk menjadi apa yang mereka inginkan dan menjadi terbaik yang mereka mampu (O'Connor dan Lages, 2004), hubungan yang kuat bagi orang-orang untuk membuat perubahan-perubahan penting dalam hidupnya (Whitworth dkk), pembelajaran, coach (yang memberi coaching) dan coachee (yang menerima coaching) memasuki kemitraan pembelajaran bersamasama (Sieler, 2003).

Berdasarkan pendapat tersebut di atas, disimpulkan coaching sebagai metode pembelajaran pada agenda habituasi Latsar 
CPNS untuk menumbuhkan motivasi dan meningkatkan kemampuan peserta pelatihan melalui interaksi antara coach dan coachee dalam menyusun dan menyajikan rancangan aktualisasi di tempat pelatihan, melaksanakan aktualisasi di tempat kerja coachee, dan menyajikan laporan aktualisasi pada akhir pelatihan.

2) Pentingnya Coaching dalam Pelatihan Pentingnya coaching dalam pelatihan didukung kajian yang menyatakan coaching sebagai pendukung pelatihan (Homan dan Miller, Recham dalam Kaswan, 2012). Emerging Leader Research Survey Summary Report oleh Center for Creative Leadership pada 2013 menyatakan semua karyawan menginginkan keterampilannya meningkat. Cara yang mereka inginkan ternyata (yang paling digemari) adalah face to face coaching di tempat kerja (Gomulya dkk, 2018: xxiv). Jennifer J. Deal, What Millennials Want from Work, menyatakan hasil riset berdasarkan data kerja lapangan dan survey dari penelitian global pada lebih dari 25.000 milenial dan 29.000 pekerja yang lebih tua di 22 negara. Salah satu poinnya berbunyi, coaching, not micromanaging-because Millennials value autonomy.

3) Prinsip dan Keterampilan Coaching Banyak prinsip dan keterampilan coaching yang dikemukakan ahli atau pakar. Keterampilan dalam praktik coaching yaitu powerful question dan active listening (Whitmore, 2017:79-153); kualitas, keterampilan dan kompetensi coaching meliputi memiliki kualitas empati, perspektif atau pandangan, fokus yang jelas, intuisi, obyektif, dan kekuatan untuk memberi tantangan kepada coachee, keterampilan mendengarkan, mengajukan pertanyaan, dan mengklasifisikan sesuai tujuan, strategi, dan tindakan (Passmore, 2010:10); delapan prinsip coaching, yaitu: semangat coaching, hubungan dan kepercayaan, bertanya dan keingintahuan, menyimak dan intuisi, umpan balik dan kesadaran, saran dan penyederhanaan, tujuan dan rencana tindakan, pertanggungjawaban dan pencapaian (Canfield dan Chee, 2016:3); sembilan prinsip dasar coaching dan mentoring, yaitu: hubungan pembelajaran, konteks, klien, coach dan mentor, hasil, kerangka proses perubahan, keterampilan/keahlian, kualitas coach dan mentor, dan praktik etis (Connor dan Pokora dalam Kaswan, 2012:19); prinsip coaching meliputi membangun kepercayaan diri, kejelasan dalam berkomunikasi, memberi dukungan, kejelasan tujuan, keterlibatan, ambil resiko, kesabaran, menjaga kerahasiaan, tidak memaksakan kehendak, bukan ajang mencari kambing hitam, fokus pada solusi, bukan masalah, dan hadir secara penuh. Keterampilan coaching meliputi mendengarkan dengan empati, memahami hal yang tidak dapat diungkapkan, memberi umpan balik yang membangun, bertanya, dan mendiagnosis (Gomulya, 2019:91-107).

Berdasarkan penjelasan di atas, disimpulkan bahwa prinsip coaching merupakan tindakan, tahapan, keterampilan atau keahlian yang dipergunakan oleh coach dan coachee pada Latsar CPNS meliputi hubungan pembelajaran, keterampilan mendengarkan, bertanya, mengklasifikasi, meringkas, merefleksi, dan memberi umpan balik, membuat tujuan, strategi, dan melakukan tindakan, hubungan dan kepercayaan, pertanggungjawaban dan pencapaian coaching agar berjalan secara efektif.

4) Model Coaching GROW

Model GROW adalah kependekan dari Goal (Tujuan), Reality (Realitas), Option (Pilihan), dan What Next atau Will (Tindakan). Struktur dasar model ini ditemukan oleh John Whitmore (2017:96) seperti gambar 1 .

\begin{tabular}{|c|c|c|c|}
\hline $\begin{array}{c}\text { Goal } \\
\text { What do } \\
\text { you want? }\end{array}$ & $\begin{array}{c}\boldsymbol{R}_{\text {eality }} \\
\text { Where are } \\
\text { you now? }\end{array}$ \\
$\begin{array}{c}\boldsymbol{O}_{\text {ption }} \\
\text { What could } \\
\text { you do? }\end{array}$ & $\begin{array}{c}\boldsymbol{W}_{\text {ill }} \\
\text { What } \\
\text { will you } \\
\text { do? }\end{array}$ \\
\hline
\end{tabular}

\section{Gambar 1. Model GROW}

Model coaching perilaku-model GROW (Goal, Reality, Option, Wrap-up), sebuah model sederhana dan efektif yang dapat diterapkan dalam semua interaksi coaching (Passmore, 2010:76); lihat gambar 2. 


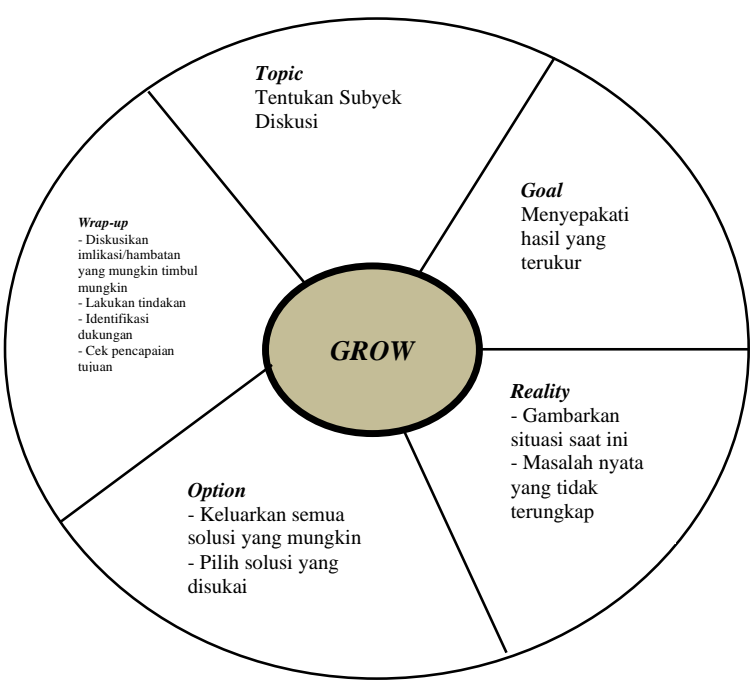

Gambar 2. Model GROW

Model GROW efektif dalam coaching, proses coaching yang efektif membutuhkan model yang juga efektif. Coaching sesuai GROW meliputi menyepakati tujuan (goal), menggali realitas (reality), masalah, keadaan, atau situasi, menggali dan menginspirasi pilihanpilihan (options) solusi, dan pernyataan komitmen atau kemavan dan rencana tindak lanjutnya (what next atau will) (Gomulya, 2019:142-154).

5) Implementasi Coaching Model GROW dalam Agenda Habituasi

Empat komponen model GROW dalam coaching agenda habituasi Latsar CPNS sebagai berikut:

a) Komponen Goal (Tujuan)

Coaching diarahkan pada pemahaman tujuan, penetapan tujuan, dan hasil yang akan dicapai dalam agenda habituasi.

b) Komponen Reality (Realitas)

Coaching dilakukan dengan menemukan isu atau masalah organisasi, menetapkan gagasan kreatif pemecahan isu organisasi, menetapkan solusi pemecahan isu pada rancangan aktualisasi.

c) Komponen Option (Pilihan)

Coaching menetapkan kegiatan dan tahapan kegiatan, menetapkan output kegiatan, menganalisis keterkaitan kegiatan dengan nilai-nilai dasar PNS yaitu akuntabilitas, nasionalisme, etika publik, komitmen mutu, dan anti korupsi, dan menganalisis keterkaitan kegiatan dengan visi dan misi organisasi, dan menganalisis keterkaitan kegiatan dengan penguatan nilai organisasi pada rancangan aktualisasi dan penyajian seminar rancangan aktualisasi.

d) Komponen Will (Tindakan)

Coaching dilakukan pada pelaksanaan aktualisasi di tempat kerja coachee, penyusunan laporan dan penyajian seminar aktualisasi.

\section{Permasalahan}

1) Apakah coaching pada agenda habituasi terkait goal (tujuan), reality (realitas), option (pilihan), dan will (tindakan)?

2) Bagaimana proses coaching pada agenda habituasi terkait goal (tujuan), reality (realitas), option (pilihan), dan will (tindakan)?

\section{Tujuan Penelitian}

1) Mendeskripsikan coaching pada agenda habituasi terkait goal (tujuan), reality (realitas), option (pilihan), dan will (tindakan).

2) Mendeskripsikan proses coaching pada agenda habituasi terkait goal (tujuan), reality (realitas), option (pilihan), dan will (tindakan).

\section{METODOLOGI}

Penelitian ini menggunakan pendekatan kualitatif. Teknik pengumpulan data dilakukan melalui studi literatur/studi kepustakaan dan dokumentasi.

\section{HASIL DAN PEMBAHASAN}

Setelah melakukan studi literatur/kepustakaan dan dokumentasi terkait empat komponen pada agenda habituasi diperoleh temuan dan pembahasan, sebagai berikut:

1) Komponen goal (tujuan)

Coach dan coachee memahami tujuan agenda habituasi pada awal sesi coaching. Coach mengajukan pertanyaan kepada coachee: Apakah anda telah memahami tujuan agenda habituasi? Coach dan coachee selanjutnya menyepakati pencapaian setiap tahapan aktualisasi dalam setiap sesi coaching.

Coaching pada tahapan ini sesuai dengan pendapat Whitmore dan Gomulya bahwa pada tahap awal coaching baik coach dan 
coachee memahami dan menyepakati tujuan coaching pada setiap sesi coaching.

2) Komponen reality (realitas)

Coach mengajukan pertanyaan kepada coachee terkait pemahaman isu sebagai reality (realitas) seperti: Bagaimana Anda memahami environmental scanning, problem solving, dan analysis dalam penetapan isu? Bagaimana isu di tempat kerja Anda? Bagaimana anda menetapkan isu di tempat kerja Anda? Bagaimana data dan fakta yang relevan dengan isu yang Anda tetapkan? Coach menganalisis keterkaitan isu dengan mata pelatihan Manajemen ASN, Pelayanan Publik, dan Whole of Government yang disampaikan oleh coachee. Coach mengajukan pertanyaan terbuka kepada coachee seperti: Bagaimana keterkaitan isu di tempat kerja Anda dengan mata pelatihan Manajemen ASN, Pelayanan Publik, dan Whole of Government?

Penetapan isu menggunakan alat bantu penetapan kriteria kualitas isu seperti; Aktual, Kekhalayakan, Problematik, dan Kelayakan. Alat bantu lainnya seperti analisis USG, sistem berpikir mind map, fishbone, SWOT, tabel frekuensi, atau dan lain sebagainya. Coach mengajukan pertanyaan bagaimana/apakah alat bantu kriteria isu yang Anda pergunakan? Bagaimana dukungan data dan fakta yang relevan dengan isu yang Anda tetapkan? Coach menganalisis akar permasalahan, aktor yang terlibat, dan peran dari setiap aktor yang disampaikan oleh coachee dikaitkan dengan mata pelatihan Manajemen ASN, Pelayanan Publik, dan Whole of Government. Coach mengajukan pertanyaan bagaimana keterkaitan akar masalah dengan mata pelatihan tersebut? Siapa aktor yang terlibat dan bagaimana peran aktor dikaitkan dengan mata pelatihan?

Coach mengajukan pertanyaan bagaimana coachee memilih partner atau role model? Bagaimana kriteria atau indikator yang akan ditiru sesuai dengan substansi materi mata pelatihan yang telah dipelajari?

Coaching pada tahapan ini sesuai dengan pendapat Whitmore yaitu menetapkan realitas. Selaras dengan Whitmore, menurut Passmore penetapan topik seringkali terjadi, seorang coachee tidak sepenuhnya memahami mengenai apa yang ingin dibicarakan, sehingga topik yang disampaikan samarsamar. Oleh karena itu, penting sekali untuk mengurai sebuah topik yang masih umum dan mendapatkan kejelasan fokus yang diinginkan coachee. Pendapat Gomulya juga menyatakan bahwa tahap ini merupakan eksplorasi terhadap realitas yang dihadapi coachee. Tujuan tahap ini adalah menemukan akar serta memperluas dan memperkaya sudut pandang coachee sehingga pada tahap berikutnya akan muncul gagasan tentang cara bergerak maju.

3) Komponen option (pilihan)

Coach menganalisis dan memvalidasi gagasan kreatif pemecahan isu dan strateginya. Coach mengajukan pertanyaan kepada coachee: Bagaimana kegiatan dan tahapan kegiatan Anda? Bagaimana output kegiatan Anda? Bagaimana keterkaitan kegiatan dengan nilainilai dasar PNS yaitu Akuntabilitas, Nasionalisme, Etika Publik, Komitmen Mutu, dan Anti Korups? Bagaimana keterkaitan kegiatan dengan visi dan misi organisasi Anda? Bagaimana keterkaitan kegiatan dengan penguatan nilai organisasi Anda?

Pada tahapan ini, menurut Whitmore coaching merupakan tindakan menetapkan pilihan. Selanjunya Passmore menjelaskan jika coachee telah menggambarkan realitasnya dengan sangat rinci, peran coach selanjutnya adalah membantu coachee memunculkan beberapa pilihan dalam mengeksplorasi untuk melangkah ke depan. Selanjunya Gomulya menjelaskan tahap ini melakukan eksplorasi terhadap pilihan-pilihan solusi.

4) Komponen will (tindakan)

Coach mengajukan pertanyaan kepada coachee: Apakah realisasi kegiatan dan outputnya sesuai dengan rencana kegiatan yang telah disusun sebelumnya? Apakah faktor pendukung dan faktor penghambat realisasi aktualisasi? Apa kaitan proses merealisasikan aktualisasi dengan substansi mata pelatihan yang peserta dapatkan sebelumnya? Bagaimana dampak internalisasi nilai-nilai yang terkandung dalam substansi mata pelatihan tersebut pada saat peserta melaksanakan habituasi? Apa potensi, tantangan dan hambatan penerapan nilai-nilai yang terkandung dalam substansi mata pelatihan terhadap organisasi.? Apa kaitan proses merealisasikan aktualisasi dengan kontribusinya 
terhadap visi-misi organisasie Bagaimana dampak aktualisasi yang peserta lakukan terhadap visi-misi organisasi? Bagaiman komitmen peserta untuk melanjutkan aktualisasi untuk seterusnya sebagai bentuk kontribusi terhadap visi-misi organisasi?

Coaching pada tahapan ini menurut Whitmore merupakan pelaksanaan tindakan. Passmore menjelaskan, tahap tindakan merupakan tindakan tepat yang harus diambil tampak jelas oleh coachee. Coachee mungkin masih memiliki beberapa pilihan, coach harus membantu untuk membatasi pilihan-pilihan tersebut. Selanjutnya Gomulya menjelaskan coaching tahap ini merupakan apa yang akan dilakukan atau komitmen apa yang akan diambil oleh coachee.

\section{KESIMPULAN}

\section{A. Kesimpulan}

Berdasarkan hasil pembahasan pada komponen goal, reality, option dan will coaching agenda habituasi di atas, disimpulkan sebagai berikut:

1) Komponen Tujuan (Goal)

Coaching goal pada agenda habituasi meliputi pemahaman tujuan, penetapan tujuan, dan hasil yang akan dicapai dalam agenda habituasi.

2) Komponen Realitas (Reality)

Coaching reality pada agenda habituasi meliputi menemukan isu atau masalah organisasi, menetapkan gagasan kreatif pemecahan isu organisasi, menetapkan solusi pemecahan isu pada rancangan aktualisasi.

3) Komponen Pilihan (Option)

Coaching option pada agenda habituasi meliputi menetapkan kegiatan dan tahapan kegiatan, menetapkan output kegiatan, menganalisis keterkaitan kegiatan dengan nilai-nilai dasar PNS yaitu akuntabilitas, nasionalisme, etika publik, komitmen mutu, dan anti korupsi, dan menganalisis keterkaitan kegiatan dengan visi dan misi organisasi, dan menganalisis keterkaitan kegiatan dengan penguatan nilai organisasi pada rancangan aktualisasi dan penyajian seminar rancangan aktualisasi.

4) Komponen Tindakan (Will)

Coaching will pada agenda habituasi meliputi pelaksanaan aktualisasi di tempat kerja coachee, penyusunan laporan dan penyajian seminar aktualisasi.

\section{B. Rekomendasi}

Berdasarkan pada kesimpulan pada komponen goal, reality, option dan will coaching agenda habituasi di atas, direkomendasikan kepada coach dan coachee sebagai berikut:

1) Komponen Tujuan (Goal)

Meningkatkan kualitas coaching coach dan coachee meliputi pemahaman tujuan, penetapan tujuan, dan hasil yang akan dicapai dalam agenda habituasi.

2) Komponen Realitas (Reality)

Meningkatkan keterampilan coach memotivasi dan membimbing coachee untuk menemukan isu atau masalah organisasi, menetapkan gagasan kreatif pemecahan isu organisasi, menetapkan solusi pemecahan isu pada rancangan aktualisasi.

3) Komponen Pilihan (Option)

Meningkatkan keterampilan coach memotivasi dan membimbing coachee untuk menetapkan kegiatan dan tahapan kegiatan, menetapkan output kegiatan, menganalisis keterkaitan kegiatan dengan nilai-nilai dasar PNS yaitu akuntabilitas, nasionalisme, etika publik, komitmen mutu, dan anti korupsi, dan menganalisis keterkaitan kegiatan dengan visi dan misi organisasi, dan menganalisis keterkaitan kegiatan dengan penguatan nilai organisasi pada rancangan aktualisasi dan penyajian seminar rancangan aktualisasi.

4) Komponen Tindakan (Will)

Meningkatkan keterampilan coach memotivasi dan membimbing coachee untuk melaksanakan tindakan dan bertanggungjawan atas pelaksanaan aktualisasi di tempat kerja coachee, penyusunan laporan dan penyajian seminar aktualisasi.

\section{REFERENSI}

Batista, Ed. 2015. HBR Guide to Coaching Employee. Boston, Massachusetts, USA: Harvard Business Review Press.

Boyatzis, Richard. E., Smith, Melvin, dan Van Oosten, Ellen. 2019. Helping People Change: Coaching with Compassion for Lifelong Learning Ad Growth. Boston, Massachusetts, USA: Harvard Business Review Press. 
Canfield, Jack dan Chee, Peter. 2016. Coaching for Breakthrough Succes. TeknikTeknik yang Telah Teruji yang Mampu Membuat Mimpi yang Tak Mungkin Menjadi Mungkin. Jakarta. Kesaint Blanc.

Gomulya, Benny, Hyacintha Susanti Jahja, dan Heria Windasuri. 2018. Coaching for Result Unlocking Human Potential to Achieve Organization's Performance. Jakarta: PT Gramedia Pustaka Utama.

Gomulya, Benny, Hyacintha Susanti Jahja, dan Heria Windasuri. 2019. Coaching Practices Menginpirasi, Menumbuhkan, dan meningkatkan Performa Tim. Jakarta: PT Gramedia Pustaka Utama.

Kaswan. Coaching dan Mentoring Untuk Pengembangan SDM dan Peningkatan Kinerja Organisasi. 2012. Penerbit Alfabeta. Bandung.

Pressmore, Jonathan (ed.). 2010. Excellence in Coaching Panduan Lengkap Menjadi Coach Profesional. Penerbit PPM. Jakarta.

Schmidt, Eric, Rosenberg, Jonathan, dan Eagle, Alan. 2019. Trillion Dollar Coach the Leadership Playbook of Silicon Valley's Bill Campbell. Carmelite House. Victoria Embankment. London: John Murray.

Whitmore, Jonathan. 2019. Coaching for Performance. The Principles and Practice of Coaching and Leadership. London. John Murray Press.

\section{Dokumen}

Peraturan LAN Nomor 12 Tahun 2018 Tentang Pelatihan Dasar CPNS.

Panduan Penulisan Laporan Aktualisasi. BPSDM Kementerian Dalam Negeri. 2018. 